УДК $327(73+\epsilon C)$

DOI: https://doi.org/10.33782/eminak2019.4(28).353

\title{
РОЗВИТОК ТРАНСАТЛАНТИЧНИХ ВІДНОСИН ЗА АДМІНІСТРАЦІЇ ДЖОНА КЕННЕДІ
}

\author{
Маргарита Лимар \\ Чорноморський національний університет імені Петра Могили (Миколаїв, Україна) \\ e-mail: rita25lymar@gmail.com \\ ORCID: http://orcid.org/0000-0001-9902-2709
}

У статті досліджуються американсько-європейські відносини за період президентства Джона Ф. Кеннеді, їх основи та розвиток. Визначено, що Дж. Кеннеді не розглядав європейський напрям зовнішньої політики як пріоритетний. Зазначається, що у контексті європейської політики, увага була зосереджена на протидії комунізму та розбудові відносин із Великою Британією, Німеччиною та Францією. Спроба створення «Атлантичного співтовариства», або «Grand Design» стала ключовою ініціативою адміністрації Дж. Кеннеді для трансатлантичної єдності. Доведено, що Франція найбільш рішуче виступала проти зміцнення американських позицій в Європі та протидіяла поширенню англосаксонського впливу на континенті.

Ключові слова: США, НАТО, Дж. Кеннеді, Ш. де Голль, «Атлантичне співтовариство»

Трансатлантичні відносини є системою, злагоджене функціонування якої десятиліттями залишається однією з умов міжнародної стабільності. Дослідження історії ïx розвитку не втрачає актуальності з огляду на численні різнорівневі зв'язки між США та країнами Європи. Більш того, саме зовнішньополітичні стратегї адміністрацій США значною мірою визначають характер американсько-європейського партнерства, яке було започатковано та стверджено у XX ст., коли європейський простір став зоною інтересів для таких президентів США як Д. Ейзенхауер (сприяв вступу ФРН до НАТО та проводив політику балансування, намагаючись контролювати європейські справи), Л. Джонсон (висловлював надію на сильну Європу як союзника), Дж. Картер (увагу було сконцентровано на концепції трилатералізму: зміцнення відносин за віссю Америка-Японія-Західна Європа), Р. Рейган (нафтодоларова монополія США стала чинником створення Європейської валютної системи, що, у свою чергу, сприяло оздоровленню трансатлантичних відносин і співпраці США з консервативними західноєвропейськими урядами на якісно новому рівні) та У.Клінтон (аналогічно до Д. Ейзенхауера вважав, що сильна Європа більше відповідала б американським національним інтересам). Натомість, президенти Дж. Кеннеді (послаблення європейського вектору), Р.Ніксон (переорієнтація зовнішньополітичних інтересів на користь Китаю та СРСР), Дж. Буш-ст. (визнання невідворотності поглиблення інтеграційних процесів і співіснування НАТО та ЄС як двох сусідніх структур) вимушено підтримували трансатлантичний діалог без особистої зацікавленості у євроінтеграційних процесах і співробітництві.

Розвиток трансатлантичних відносин за президентства Дж. Кеннеді становить інтерес, зважаючи на його відхід від проєвропейської політики, якою прославився його попередник, Д. Ейзенхауер, - прихильник ідеї створення «Сполучених Штатів Європи» та укладач неформальної «Великої трансатлантичної угоди» $з$ європейцями. Серед американських і західноєвропейських науковців, які досліджували зовні- 
шню політику Дж. Кеннеді можна відзначити Е.Тілфорда (E.Tilford) та Ф. Гевіна (F. Gavin) (зосередилися на вивченні безпекових аспектів концепції «гнучкого реагування» адміністрації Дж. Кеннеді), Р. Паулі (R. Pauly) (відзначив наміри США контролювати потенційних союзників ціною заміщення керівних посад лояльними до Сполучених Штатів кандидатурами), Дж. Холмса (J. Holmes) (засвідчив різновекторність зовнішньої політики Дж. Кеннеді), А. Пріста (A. Priest) та Дж. Жока (J. Giauque) (відзначили роль НАТО як інструменту впливу США на європейські процеси та розглянули перспективи створення «Атлантичного співтовариства»). Окрім того, увага дослідників значною мірою зосереджена на аналізі відносин США та Франції з огляду на політику Ш. де Голля, який був категорично проти зміцнення американських позицій в Європі.

Серед вітчизняних американістів цікавими видалися дослідження М. Марущака (розкрито трансформацію відносин за напрямом США-ФРН-НАТО періоду адміністрації Дж. Кеннеді), М. Ратнікова (розглянуто еволюцію європейської політики США 3 огляду на євроінтеграційні процеси), А. Худолія (простежено формування та еволюція зовнішньополітичних пріоритетів США шляхом аналізу публічної риторики президентів, зокрема, Дж. Кеннеді). Українські вчені здебільшого зосереджують свої наукові пошуки на загальних тенденціях зовнішньої політики Дж. Кеннеді, виникненні та врегулюванні Карибської кризи, воєнній кампанії США у В’єтнамі, політиці щодо Західного Берліну тощо, та розглядають їх у контексті загальної історії становлення трансатлантичних відносин. Тож, метою цієї статті є доповнення вітчизняних розвідок комплексним вивченням трансатлантичних відносин за період адміністрації Дж. Кеннеді та, зокрема, європейського вектору зовнішньополітичного курсу США.

Перш за все, важливо відзначити, що основою американської зовнішньої політики адміністрації Дж. Кеннеді стала концепція лібералізму, що передбачала досягнення консенсусу в процесі переговорів задля схвалення спільного політичного курсу. У своїй інавгураційній промові, 20 січня 1961 р., Дж. Кеннеді закликав міжнародну спільноту до пошуків порозуміння та відмови від гонки озброєнь, наголосивши при тому, що США приєднаються до будь-якої нації в її боротьбі за свободу і рішуче захищатимуть інтереси Північної та Південної Америк. У промові Дж. Кеннеді не йшлося про європейських партнерів так само, як і не було мови про НАТО. Натомість, президент назвав ООН останньою та кращою надією у світі, де військові інструменти впливу випереджають дипломатичні ${ }^{1}$. Як зазначає А. Худолій, серед пріоритетів Дж. Кеннеді у формуванні зовнішньополітичного курсу чітко простежувалися тенденції до «зміцнення ООН», «допомоги у розбудові мирного світу», «зміцнення військових союзів» тощо². Таким чином, від початку свого президентства Дж. Кеннеді окреслив загальний характер зовнішньої політики, але не надав Європі чітких гарантій протекції США.

Пізніше наміри Дж. Кеннеді спрямувати міжнародні переговори щодо питань озброєння у дипломатичне русло знайшли відображення у публічному звернені

\footnotetext{
${ }^{1}$ Inaugural Address of President John F. Kennedy, Washington, D. C., 20 January 1961 // John F. Kennedy Presidential Library and Museum: The official website. URL: https://www.jfklibrary.org/Research/Research-Aids/Ready-Reference/JFK-Quotations/InauguralAddress.aspx

2 Худолій А.О. Публічний дискурс у зовнішньополітичній діяльності президентів США (19452012 рр.): дис.... д. політ. наук: 23.00.04. Острог, 2013. С. 163.
} 
президента США від 26 липня 1963 р. до американського народу з приводу Договору про заборону ядерних випробувань. Підкреслюючи виняткову роль миротворців американської нації, Дж. Кеннеді закликав співгромадян, незважаючи на час і відстань, першими зробити крок і вийти з «тіні війни»3.

Разом $з$ тим, необхідно зазначити що, доктрина гнучкого реагування, якої притримувався Дж. Кеннеді, передбачала не відмову від озброєння, а його переорієнтацію. Вона включала зменшення одиниць стратегічних бомбардувальників і збільшення кількості винищувачів-бомбардувальників для підтримки більшого військового потенціалу. Для забезпечення підтримки якісної ядерної переваги Стратегічного авіаційного командування США, «гнучка відповідь» включала в себе розміщення 1000 ракет «Мінутмен» (англ. «Minuteman») у підземних силосах, що працювали на твердому паливі, та подвоєння кількості ракетних підводних човнів «Поларіс» (англ. «Polaris») 4 . Вона також передбачала можливість ведення обмеженої ядерної війни та, як заявляв міністр оборони США Р. Макнамара, у секретній промові до членів НАТО в Афінах 5 травня 1962 р., надавала змогу Сполученим Штатам «контролювати і направляти свої ядерні сили під час кризи», в залежності від військової ситуації5.

Таким чином, всупереч офіційним заявам, Сполучені Штати були готові до військового реагування на комуністичну агресію. Однак, увага була все ж зосереджена на зміцненні дипломатичних контактів, зокрема, із потенційними «друзями» серед націй-прибічників Руху неприєднання. Сполучені Штати мали намір захищати інтереси можливих союзників «за будь-яку ціну» та розглядали навіть можливість заміщення лідерів деяких країн у разі розбіжності їх політичних інтересів з позицією США6. За оцінками істориків з Держдепартаменту США, саме така політика Дж. Кеннеді, врешті решт, привела Сполучені Штати до частих, інтенсивних зіткнень з СРСР і вивела світ на межу ядерної війни7 .

Країни Західної Європи сприйняли ідеалістичний підхід наступника Д. Ейзенхауера до ведення міжнародної політики 3 недовірою. Президент Дж. Кеннеді (як і його наступник - Л. Джонсон) підтримував ідею того, що американська військова відповідь має бути прямо пропорційна рівню небезпеки. На тлі того, що європейський вектор більше не був пріоритетом Сполучених Штатів, - сфера інтересів США тепер рівномірно охоплювала «Лаос, Берлін, Південну Азію, Кубу та Африку»8, - політика гнучкого реагування у межах НАТО викликала нерозуміння з боку європейських держав-членів Альянсу. Більш того, серед союзників по НАТО існували розбіжності у підходах щодо врегулювання німецького й інших питань. Як зазначав держсекретар США Д. Раск в одному з листів від 30 грудня 1961 р. до Генерального

\footnotetext{
${ }^{3}$ Address to the Nation on the Nuclear Test Ban Treaty, 26 July 1963 // John F. Kennedy Presidential Library and Museum: The official website. URL: https://www.jfklibrary.org/AssetViewer/ZNOo49DpRUa-kMetjWmSyg.aspx

4Tilford E.H. President John F. Kennedy's national security legacy // The Center for Vision \& Values at Grove City College: The official website. 2013. November 20. URL: http://www.visionandvalues.org/2013/11/president-john-f-kennedys-national-security-legacy/

5 Gavin F.J. The myth of flexible response: United States strategy in Europe during the 1960s. The International History Review. № 4 (23). 2001. P. 850.

6 Pauly R.J.Jr. The Ashgate research companion to US foreign policy. London: Routledge, 2016. P. 94-95.

7 The world in 1961 // Office of the Historian, Bureau of Public Affairs, United States Department of State. URL: https://history.state.gov/departmenthistory/short-history/jfk

${ }^{8}$ Holmes J.E. The mood / interest theory of American foreign policy. University Press of Kentucky, 2015. P. 97.
} 
секретаря НАТО Д. Стіккера, члени Альянсу (зокрема, США, Франція, Німеччина та Велика Британія) мали проблеми не стільки з СРСР, скільки із взаєморозумінням між собою. Таке положення справ свідчило про втрату балансу у трансатлантичних відносинах й опори для самих США9.

Члени НАТО переймалися через вірогідність зменшення військової присутності США в Європі. Посилення англо-саксонського впливу на континенті спричиняло занепокоєння європейських урядів, проте вони відмовлялися збільшувати військовий потенціал, сподіваючись, що це змусить США тримати в Європі мінімум 400 тис. військових. Перспективи розвитку трансатлантичних відносин залежали не лише від військово-оборонного аспекту співпраці, але й від економічної детермінанти. Вашингтон активно витрачав фінанси на військові потреби за межами Європи, поки існував профіцит торгового балансу на трансатлантичному просторі. Однак, стрімке економічне зростання у 1950-х рр., а також конкуренція з боку Спільного ринку, змусили США переглянути фінансову політику за кордоном ${ }^{10}$.

«Атлантичне співтовариство» (англ. «Grand Design») стало політичною ініціативою Сполучених Штатів ${ }^{11}$. Даний план був далекоглядним і передбачав вступ Великої Британії до Європейського Спільного ринку. Такий підхід супроводжувався спрощенням тарифів на трансатлантичному просторі і, як наслідок, збільшенням експорту. Європейські держави мали ідентифікувати себе як центр військової інтеграції та збільшити власні витрати на інтеграційні процеси. Ідею «Атлантичного співтовариства» було розвинуто з метою створення єдиного надійного союзника на європейському континенті, який мав допомагати Сполученим Штатам і підтримувати їх політику.

Необхідно зазначити, що амбіції Сполучених Штатів як однієї з найвпливовіших держав на світовій арені не дозволяли їм повною мірою брати до уваги побажання партнерів. Консультації з європейськими урядами були необхідні США, щоб, перш за все, повідомляти про свою позицію. Таке положення справ не задовольняло Францію в особі генерала Ш. де Голля ${ }^{2}$, який у розмові 3 французьким письменником і дипломатом Р. Пейрефіттом зауважив, що Франція була піонером у питанні скасування рабства та захисті права людини розпоряджатися власною долею, та висловив впевненість у тому, що «Франція є світлом світу, а їі геній - це просвітлення всесвіту» ${ }^{13}$. Більше того, генерал Ш. де Голль вимагав докорінної трансформації міжнародного порядку та нівелювання статус-кво в Європі, оскільки багатополярний світ був більш стабільним і безпечним, аніж система, яка базувалася на суперництві наддержав. На його глибоке переконання, сили Великої Британії, Франції, Німеччини, Росії, Італії та Японії формували систему рівноваги (англ. «еquilibrium»), яку пору-

\footnotetext{
${ }^{9}$ Rusk D. Telegram from the Department of State to the Mission to the North Atlantic Treaty Organization and European Regional Organizations, Washington, 30 December 1961 // United States Department of State, Office of the Historian, Bureau of Public Affairs. URL: https://history.state.gov/historicaldocuments/frus1961-63v13/d122

10 Ратніков M.I. Європейська політика США в контексті політичних трансформацій у ЄС: дис... канд. політ. наук: 23.00.04. Київ, 2013. С. 59.

11 Priest A. Kennedy, Johnson and NATO: Britain, America and the dynamics of Alliance, 1962-68. London: Routledge, 2006. P. 36.

12 Paterson T.G. Kennedy's questfor victory: American foreign policy, 1961-1963. Oxford University Press, 1989. P. 28.

13 Martin G.J. General de Gaulle's Cold War: Challenging American hegemony, 1963-68. Berghahn Books, 2013. P. 193.
} 
шили США та СРСР14. Таким чином, супротив Ш. де Голля миритися із самопозиціонуванням США як першочергової міжнародної потуги було цілком логічним.

Новий погляд адміністрації Дж. Кеннеді щодо зменшення ролі ядерного компонента на користь «м'яких» інструментів НАТО, викликав занепокоєння у Західній Європі, країни якої не бажали відмовлятися від колишньої масштабної військової підтримки США. Однак, Вашингтон знайшов вихід з цієї ситуації, запропонувавши на трансатлантичному ринку американське озброєння як компенсацію зменшення власних витрат на врегулювання військово-оборонних питань в Європі. 3 одного боку, це дало можливість послабити загальну напруженість в Альянсі, а з іншого призвело до негативних наслідків у відносинах з Великою Британією, яка була долучена до переговорів щодо ядерної зброї15.

У адміністрації Дж. Кеннеді складалися напружені відносини не лише з Великою Британією, але й з Францією, яка взяла курс на відновлення своєї могутності на чолі з Ш.де Голлем. Французький лідер відверто критикував зовнішню політику США щодо Європи, оскільки США пропагували рівність і взаємовигідні відносини для потенційних партнерів на всіх рівнях, однак, насправді, захищали власні гегемоністські амбіції. Американське керівництво в Європі опинилося під загрозою, коли Ш. де Голль поставив під сумнів доцільність умов «Великої трансатлантичної угоди», припустивши, що США не будуть захищати повною мірою Західний світ від СРСР. Починаючи з 1963 р. непохитний вплив США у Західній Європі почав слабнути ще й тому, що західноєвропейські країни випереджали Сполучені Штати у показниках промислового зростання, наслідком якого стало суттєве скорочення (майже вдвічі) золотовалютного запасу США і його зростання в європейських банках. Довгострокова політика Ш. де Голля була спрямована на підрив економіко-фінансової могутності Сполучених Штатів (в Європі) та політико-мілітаристського домінування HATO.

14 січня 1963 р. на прес-конференції, яка ознаменувала собою початок нового етапу у формуванні західноєвропейської єдності, Ш. де Голль розкритикував грандіозний задум Дж. Кеннеді та виявив категоричну незгоду щодо вступу Великої Британії до Спільного ринку16. 3 точки зору Франції, її вступ до об'єднання призвів би, за принципом доміно, до його надмірного розширення та подальшої неефективності. Більше того, генерал висловився проти проекту американського президента об'єднати стратегічні збройні сили Атлантичного пакту під керівництвом США. Створення Багатосторонніх ядерних сил (англ. Multilateral Nuclear Force), що передбачали злиття британських і французьких ядерних сил з частиною американських під командуванням НАТО, також виявилося неприйнятним ${ }^{17}$. Пропозицію щодо подібного «ядерного об'єднання» французький лідер вважав спробою дискредитувати Францію як потужну державу та позбавити її можливості власноруч розпоряджатися своїм ядерним потенціалом. Так само як і пропозицію щодо запрошення Великої

\footnotetext{
14 Ibid. P. 195.

15 Giauque J.G. Grand designs and visions of unity: The Atlantic powers and the reorganization of Western Europe, 1955-1963. The University of North Carolina Press, 2002. P. 116.

${ }_{16}$ De Gaulle Ch. EU speech (press conference by President de Gaulle, Paris, 14 January 1963) // The University of Luxembourg's CVCE: The official website. URL: https://www.cvce.eu/content/publication/1997/10/13/5b5d0d35-4266-49bc-b770-

b24826858e1f/publishable_en.pdf

17 Giauque J.G. Grand designs and visions of unity: The Atlantic powers and the reorganization of Western Europe, 1955-1963. P. 116.
} 
Британії до Спільного ринку, Ш. де Голль розглядав створення спільної ядерної потуги як одну зі спроб поновити та зміцнити англо-американський союз на континенті.

Франція сподівалася з часом «використати» ФРН у суперництві із США, зважаючи на вразливість останніх по відношенню до СРСР18. Проте, необхідно підкреслити лояльність Німеччини до США, яка була прилюдно підкреслена у 1963 р. під час ратифікації німцями Єлисейського договору про франко-західнонімецьке співробітництво. Представники ФРН наполягли на тому, щоб до договору була додана преамбула, яка фіксувала такі положення: магістральним напрямом зовнішньої політики ФРН $\epsilon$ тісний союз із США та інтеграція до структур НАТО; пріоритетом геополітичних перетворень на континенті є наднаціональна Європа, тому участь Великої Британії у Спільному ринку визнана необхідністю ${ }^{19}$. Такий крок Німеччини сприяв суттєвому погіршенню франко-західнонімецьких відносин, незважаючи на першочергові цілі Єлисейського договору. 3 січня 1963 р. зазначений договір взагалі було нівельовано. Пізніше, коли президентом США став Л. Джонсон, зовнішньополітичний курс було переорієнтовано на війну у В’єтнамі. Уряд ФРН був вкрай занепокоєний таким становищем справ, оскільки безпека Німеччини у ті роки надто залежала від американського контингенту в Європі.

У той же час, Франція скористалася ситуацією для послаблення американського впливу в Європі. Канцлер Німеччини К. Аденауер був змушений подати у відставку, оскільки його політика зближення з Францією викликала у європейців занепокоєння та недовіру. Після обрання Л. Ергарда новим канцлером ФРН у 1963 р., новообраний міністр закордонних справ Г.Шредер зосередив увагу на зміцненні німецькоамериканського співробітництва і відносини з Францією на той час були остаточно зіпсовані.

У 1958 р. з метою продемонструвати світові військовий потенціал Франції після розпаду колоніальної імперії, генерал де Голль згорнув переговори щодо ядерної зброї між Італією, Німеччиною і Францією та вивів останню на суверенний шлях імплементації національної ядерної програми. Наміри французького лідера було стверджено у його виступі 3 листопада 1959 р. в Паризькій Військовій школі Еколь Мілітер (École Militaire), коли він наголосив на першочерговості власної системи захисту та зазначив, що «Франція захищає сама себе, для себе, і власними методами» 20 . Як результат, 13 лютого 1960 р. відбулися перші ядерні випробування Франції у пустелі Сахара. Раніше США мали змогу зміцнити відносини з Францією, надавши для продажу ядерні матеріали, проте реальне посилення будь-якої з європейських держав не входило в їх плани. Через відсутність згоди щодо постачання американської сировини, Франція відмовилася купувати значні об'єми військової продукції США, включаючи зброю. Маючи за мету відновити велич Франції та сприяти консолідації Європи на проєвропейських умовах, Ш. де Голль вважав, що Сполучені Штати не мали права втручатися у справи європейців.

Президент Дж. Кеннеді був обурений таким підходом Франції та попередив про зняття своїх гарантій безпеки. Під час Кубинської кризи стало остаточно зрозуміло, що союзники США по НАТО фактично не в змозі впливати на прийняття рішень. У

\footnotetext{
18 Shennan A. De Gaulle: Profiles in power. Routledge, 2014. P. 118.

19 Марущак М.Й. Історія дипломатичних відносин у XX сторіччі. Вінниця: Нова Книга, 2008. С. 276.

${ }^{20}$ Schneider M. Nuclear France abroad: History, status and prospects of French nuclear activities in foreign countries. Paris: Mycle Schneider Consulting, 2009. P. 10.
} 
1963-1964 р. генерал де Голль зробив ще декілька відкрито антиамериканських кроків. Вашингтон і Париж мали взаємну недовіру, що сприяло охолодженню відносин між державами. Проте, США продовжували розглядали Францію як терпимого партнера у воєнні часи.

Французько-німецьке незадоволення односторонністю рішень, ухвалених Вашингтоном, звело нанівець ініціативу створення «Атлантичного співтовариства». Ч.Болен, американський посол у Франції з 1956 по 1958 рр., зазначав про Ш.де Голля наступне: «Він і надалі буде розглядати будь-які кроки стосовно так званого «Атлантичного співтовариства» як спробу Сполучених Штатів, через процес «інтеграції», встановити контроль над Європою»21. Західноєвропейські політики пильно слідкували за кожним кроком США, пам'ятаючи їх участь у світових війнах. Окрім того, не була забута і позиція Сполучених Штатів щодо Алжиру. Італійський і Німецький уряди мали досить теплі відносини з Францією, проте їх громадяни виступали з підтримкою антиколоніального руху. Тож американці займали тоді сторону африканської держави, намагаючись віддалити Фронт національного визволення Алжиру (ФНВ) від СРСР22. Вперше американські фахівці зазначили, виходячи з настроїв двох вагомих європейських потуг, що єдина, об’єднана Європа може спричинити для США більше проблем, аніж принести вигоди. Таким чином, адміністрація Дж. Кеннеді була змушена відмовитися від створення «Атлантичного співтовариства».

Отже, зовнішня політика адміністрації Дж. Кеннеді дійсно характеризувалася відходом від курсу Д. Ейзенхауера та не сприяла зміцненню трансатлантичних зв'язків. Ïї пріоритетом було обрано багатовекторну політику та протистояння комуністичній загрозі. Публічна риторика Дж. Кеннеді йшла урозріз із реальними діями США, які зберігали військовий потенціал і були ладні долучатися до збройних конфліктів задля досягнення власних інтересів. Європейська політика США балансувала на межі взаємовідносин між такими провідними європейськими державами як Велика Британія, Франція та, на перспективу, Німеччина. Франція в особі генерала Ш. де Голля виступала рішуче проти посилення позицій США в Європі, про що свідчили офіційні заяви Ш. де Голля, протидія зміцненню англо-американського союзу на континенті та реалізація власного ядерного потенціалу. Окрім того, Франція не вважала доцільним долучення Великої Британії до Спільного ринку, що значною мірою унеможливило створення «Атлантичного співтовариства». Тож, за сукупністю обставин, найбільш масштабна проєвропейська ініціатива Дж. Кеннеді так і не була реалізована.

\section{REFERENCES}

Gavin, F.J. (2001). The myth of flexible response: United States strategy in Europe during the 1960s. The International History Review, 4 (23), 847-875.

Giauque, J.G. (2002). Grand designs and visions of unity: The Atlantic powers and the reorganization of Western Europe, 1955-1963. Chapel Hill, NC: The University of North Carolina Press.

Holmes, J.E. (2015). The mood / interest theory of American foreign policy. Lexington, KY: University Press of Kentucky.

Khudolii, A.O. (2013). Publichnyi dyskurs u zovnishnopolitychnii diialnosti prezydentiv SShA (1945-

\footnotetext{
21 Reyn S. Atlantis lost: The American experience with De Gaulle, 1958-1969. Amsterdam University Press, 2010. P. 178.

22 Мітькіна О. Алжирська криза та повернення до влади Шарля де Голля // Україна-Європа-Світ. Міжнародний збірник наукових праць. Серія: Історія, міжнародні відносини. 2012. Вип. 9. С. 138.
} 
2012 rr.) [Public discourse on foreign policy activities of the U.S. Presidents (1945-2012)] (PhD dissertation). Ostroh [in Ukrainian].

Martin, G.J. (2013). General de Gaulle's Cold War: Challenging American hegemony, 1963-68. New York, NY: Berghahn Books.

Marushchak, M.Y. (2008). Istoriia dyplomatychnykh vidnosyn u XX storichchi [History of diplomatic relations in the XX century]. Vinnytsia: Nova Knyha [in Ukrainian].

Mitkina, 0. (2012). Alzhyrska kryza ta povernennia do vlady Sharlia de Hollia [Algerian crisis and returning to power of Sharl' de Gaulle]ю Ukraina-Yevropa-Svit. Mizhnarodnyi zbirnyk naukovykh prats. Seriia: Istoriia, mizhnarodni vidnosyny, 9, 133-139 [in Ukrainian].

Paterson, T.G. (1989). Kennedy's quest for victory: American foreign policy, 1961-1963. Oxford: Oxford University Press.

Pauly, R.J. Jr. (2016). The Ashgate research companion to US foreign policy. London: Routledge.

Priest, A. (2006). Kennedy, Johnson and NATO: Britain, America and the dynamics of Alliance, 1962-68. London: Routledge.

Ratnikov, M.I. (2013). Yevropeiska polityka SShA v konteksti politychnykh transformatsii u YeS [The European policy of the USA in the context of political transformation in the EU]. (PhD dissertation). Kyiv [in Ukrainian].

Reyn, S. (2010). Atlantis lost: The American experience with De Gaulle, 1958-1969. Amsterdam: Amsterdam University Press.

Schneider, M. (2009). Nuclear France abroad: History, status and prospects of French nuclear activities in foreign countries. Paris: Mycle Schneider Consulting.

Shennan, A. (2014). De Gaulle: Profiles in power. London: Routledge.

Tilford, E.H. (2013). President John F. Kennedy's national security legacy. The Center for Vision \& Values at Grove City College: The official website. Retrieved from: http://www.visionandvalues.org/2013/11/president-john-f-kennedys-national-security-legacy/

\section{Margaryta Lymar}

(Petro Mohyla Black Sea National University, Mykolaiv, Ukraine)

ORCID: https://orcid.org/0000-0001-9902-2709

\section{The Development of the Transatlantic Relations at John Kennedy's Administration}

The American-European relations during John F. Kennedy's presidency, their basics and development are studied in the paper. It is stated that as opposed to D. Eisenhower who considered strong Europe to be more equitable to the American national interests, J. Kennedy did not consider the European line of foreign policy as a prior. It is noted that in the context of the European policy, great attention was paid to the counteraction of communism and the development of relations with Great Britain, Germany, and France as the partners in NATO.

The Atlantic Community or «Grand Design» became a political initiative of the United States that contemplated the entry of Great Britain to the European Common Market. The European states had to identify themselves as the center of military integration and to increase their expenses on the integration processes. The idea of «Grand Design» was developed to create a common reliable ally on the European continent, which had to help the USA and support its policy.

In effect, this initiative of J. Kennedy's administration became key for transatlantic unity. At the same time, it is proved that France most resolutely opposed the entry of Great Britain to the Common Market because of the prospects of Anglo-Saxon influence spreading on the continent. The policy of general Ch. de Gaulle became the main counteraction to the United States in Europe where France intended to secure superiority.

The fact that J. Kennedy's administration was guided by the concept of liberalism in the issues of foreign policy formation is pointed out in the paper. The U.S. President called the UN the last and the best hope in the world in which military instruments of influence advance the diplomatic ones. J. Kennedy resolutely opposed nuclear tests, however, he did not refuse the doctrine of flexible reaction, which granted the right of the USA to control and direct the 
nuclear forces during the crisis, depending on the military situation. Thus, the dualistic character of J. Kennedy's administration policy and the actual course towards preserving the leading position in the world and the intention to control the policy of potential partners can be retraced.

Keywords: USA, NATO, J. Kennedy, Ch. de Gaulle, Atlantic Community 